\title{
FRUITS AND SEEDS FROM AN IRON AGE RITUAL OF COMMENSALITY IN FRIJÃO (BRAGA, NW PORTUGAL)
}

\author{
JOÃO PEDRO TERESO ${ }^{(1,2)} \&$ VÍTOR MANUEL FONTES SILVA ${ }^{(3)}$
}

\begin{abstract}
:
Frijão is a peculiar Iron Age place in Northwest Portugal. Its peculiarity derives mostly from what appears to be the remains of a ritual of commensality found in a pit or ditch.

Structures in Frijão were exclusively made of perishable materials. These were destroyed by an apparently man-made and ritual fire that appears to be articulated with a riveted cauldron. In the main structure of the site - a large pit or ditch - several ceramic vessels of different typologies, including several inner-wing pots seem to have been disposed and sealed quickly after being used. In this same structure, fruits of different species were found in association with frequent charcoal and ashes. The analysis that were carried out led to the identification of Quercus acorns and three crops: naked wheat (Triticum aestivum / durum), emmer (Triticum turgidum subsp. dicoccum) and broomcorn millet (Panicum miliaceum).

Unfortunately no sampling strategy was implemented during the field work which makes it impossible to evaluate whether the carpological remains that were studied are representative of what was actually there. It is clear that this context is of the utmost relevance for the understanding of social practices in the regional Iron Age, but unsuitable field work makes its interpretation more difficult.
\end{abstract}

Key-words: Frijão, Cereals, Acorns, Ritual of commensality, Iron Age

Resumo:

\begin{abstract}
Frutos e sementes de um ritual de comensalidade da Idade do Ferro no sítio de Frijão (Braga, NW de Portugal) Frijão, localizado no município de Braga, é um sítio da Idade do Ferro com características peculiares. O seu carácter único resulta principalmente dos testemunhos de rituais de comensalidade encontrados numa estrutura negativa.

As estruturas de Frijão eram constituídas por materiais perecíveis que foram destruídos por um incêndio, aparentemente para fins rituais, que parece estar relacionado com um caldeirão de rebites. Na principal estrutura do sítio - uma grande estrutura negativa - vários recipientes cerâmicos de diferentes tipologias, incluindo vários vasos de asa interior, parecem ter sido utilizados e rapidamente amortizados. Nesta mesma estrutura, frutos de diferentes espécies foram encontrados em associação com abundantes carvões e cinzas. As análises realizadas permitiram identificar bolotas (Quercus) e três cultivos: trigo de grão nu (Triticum aestivum/durum), trigo de grão vestido (Triticum turgidum subsp. dicoccum) e milho-miúdo (Panicum miliaceum).

Infelizmente, não foi implementada qualquer estratégia de recolha de amostras sedimentares durante os trabalhos de campo, tornando impossível perceber se os vestígios carpológicos estudados são representativos do que se encontrava no contexto arqueológico. É evidente a relevância deste contexto para a compreensão das práticas rituais e relações sociais na região durante a Idade do Ferro mas a metodologia de campo adotada não foi adequada, o que torna a interpretação ainda mais difícil.
\end{abstract}

Palavras-chave: Frijão, Cereais, Bolotas, Rituais de comensalidade, Idade do Ferro

\section{INTRODUCTION}

A peculiar archaeological context in an Iron Age pit at Frijão has been interpreted as the result of ritual commensality (SILVA 2013, 2014). Early studies were focused mostly on specific artefacts that were recovered in this context, namely the riveted cauldron (SILVA 2013). Still palaeobiological material was also recovered.

Thus, with this carpological study we intended to identify the fruits that were recovered in this context. Still, since no sampling strategy was implemented during the field work, it was assumed from the beginning that interpretations regarding the archaeobotanical assemblages would be severely limited and it would not be possible to fully understand the role of the carpological remains in the commensality rituals that seem to have taken place at Frijão. Nevertheless, considering the relevance of the archaeological context, it is important to make public the available data.

\footnotetext{
(1) InBIO - Rede de Investigação em Biodiversidade e Biologia Evolutiva, Laboratório Associado, jptereso@gmail.com

${ }^{(2)}$ CIBIO - Centro de Investigação em Biodiversidade e Recursos Genéticos, Universidade do Porto.

${ }^{(3)}$ CITCEM/UM - Centro de Investigação Transdisciplinar Cultura, Espaço e Memória, Departamento de História da Universidade do Minho, Campus de Gualtar, 4710-057, Braga, Portugal, vitorsilva.arq@gmail.com
} 


\section{THE ARCHAEOLOGICAL SITE}

\subsection{Location}

The archaeological site of Frijão was located in the place with the same name, belonging to the parish of Cunha, county and district of Braga, the old province of Minho in northern Portugal.

The geographic coordinates in the WGS 84 system are: Latitude $41^{\circ} 29$ '33" N; Longitude 8³1' 16" W.
Frijão was located in a small platform in the southeast slope of the mount of Frijão (Fig. 1), at an altitude of $140 \mathrm{~m}$ and in the vicinity of an open and fertile valley. About $150 \mathrm{~m}$ south and west of this location, there are two streams that drain into the Ribeira da Levegada, a subsidiary of the Este River, within the Ave basin. Besides an industrial forest of pines and eucalyptus, oak, cork oak, heather, bracken and shrubby Leguminosae are also found.

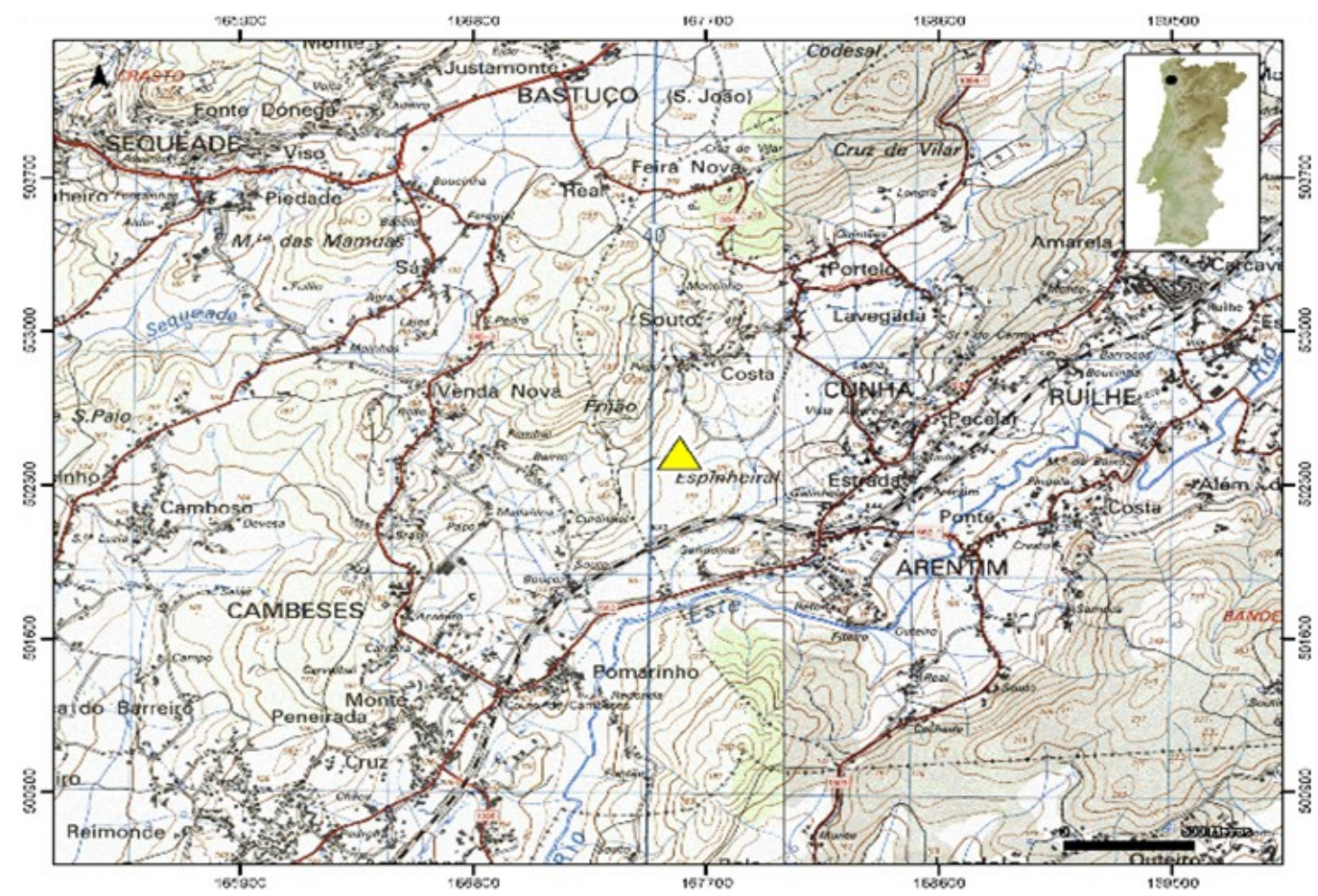

Fig. 1. Location of the archaeological site of Frijão in Carta Militar de Portugal, sheets 69-70, scale 1:25 000.

Fig. 1. Localização do sítio arqueológico de Frijão na Carta Militar de Portugal, folhas 69 e 70, escala 1:25000.

\subsection{The excavation}

Frijão was discovered in 2003 by Rui Barbosa of Palimpsesto-Estudo e Preservação do Património Cultural, Lda. during clay extraction activities of the project «Remodelação da Linha do Minho: Troço Nine-Braga e Estação de Braga». The amount of archaeological findings led to an archaeological excavation in 2004 under the coordination of Sandra Salazar Ralha working for Archeoestudos, Investigação Arqueológica, Lda. After the excavation, the site was destroyed.

The results of the excavation were never published, hence all contextual information derives from the archaeological report (RALHA 2004). Many archaeological artefacts from Frijão are part of the permanent exhibition of the Regional Museum of Archaeology D. Diogo de Sousa (MDDS) and the site has been inventoried (AZEVEDO \& BARBOSA 2004-2005; FERREIRA 2012) or briefly mentioned (BETTENCOURT 2005). Only recently the study of the archaeological artefacts was carried out (SILVA 2013, 2014).
Four test pits $\left(121 \mathrm{~m}^{2}\right)$ were excavated (RALHA 2004). Test pits 1,3 and 4 were located on three contiguous areas on the northern part of the platform (Sector 1, according to SILVA 2014). Test pit 2 was located in the southern part of the platform (Sector 2, according to SILVA 2014). The carpological material that we analysed was recovered in Sector 1.

\subsubsection{Sector 1}

In Sector 1, two large feature interfaces (Structure 1 and 2) were identified, cutting the bedrock, locally consisting on porphyroid granite (MEDEIROS \& TEIXEIRA 1969).

Structure 1 was located in the test pits 1 to 4 . The shape of this feature interface remains unknown because it was partially destroyed during recent clay extraction activities. Still, the part that was preserved suggests it had a rounded contour in plan view and it is clear that it exceeded $5 \mathrm{~m}$ in size. Its depth would be approximately 1.90m (Fig. 2) (SILVA 2014).

Structure 2 was a ditch identified in test pit 3 (SILVA 2014). Both structures were connected (RALHA 2004; SILVA 2014). 
Since no radiocarbon date was obtained, the chronology of Frijão was based on the forms and the technical characteristics of the ceramic vessels, namely forms $1 \mathrm{a}, 1 \mathrm{~b}$ and $1 \mathrm{c}, 2,3 \mathrm{~b}$ and 4 of M. Martins (1990). Form 4 vessels (inner-wing pots) from Frijão have rounded lips and wings of tubular section, which in the Cávado valley are typical from the Early Iron Age (MARTINS 1990). Such chronology is also suggested by the numerous metal fragments from a riveted cauldron (SILVA 2013). The chronological boundaries of the regional Early Iron Age are positioned between the $6^{\text {th }}$ and $5^{\text {th }}$ centuries $\mathrm{BC}$ by $\mathrm{M}$.
Martins (1990) and between the $4^{\text {th }}$ and $2^{\text {nd }}$ centuries BC by A.M. S. Bettencourt (1999, 2005).

Frijão is not interpreted as a settlement but rather as a place sporadically used by communities from one or several settlements in the region for rituals of commensality (SILVA 2014). This interpretation is based on the dimension of the site, together with the typology of its structures and the artefacts that they contained. Such assumption derives also from comparisons with similar sites in central Europe, namely in France and Germany (vide infra).
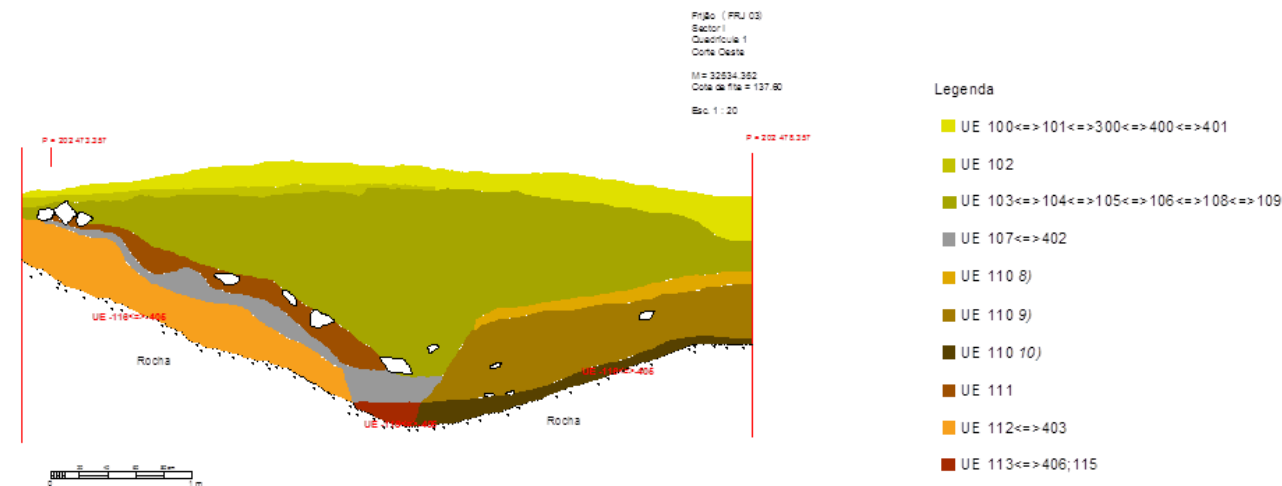

Fig. 2. Section of Structure 1 of the Sector 1, test pit 1. (SILVA 2014).

Fig. 2. Secção da Estrutura 1 do Sector 1, sondagem 1 (SILVA 2014).

\section{MATERIALS AND METHODS}

The archaeological excavation was carried out without any soil sampling strategy for future archaeobotanical studies. Plant remains were handpicked during the excavation of two consecutive layers from Structure 1, namely layers $[107=402]$ and [111] (Fig. 2). Both layers presented clear signs of extensive fire which, as mentioned above, seem to be the result of deliberate human actions in order to destroy and seal the context.

Out of any preconceived strategy, two soil samples were recovered in a peculiar context. According to the archaeological records, these two soil samples came from the interior of a vessel (mug) within layer [109] (Fig. 3).

The identification of the carpological remains was done by comparing them with the reference collection of the Porto Herbarium (PO) in the University of Porto, as well as with anatomical atlases.

The identification of the wheat grains followed the criteria of Hillman et al. (1996), Buxó (1997) and S. Jacomet (2006): Triticum aestivum/durum grains are oval or oval-roundish, with maximum width in the center or near the scutellum and blunt ends; it has a swollen aspect and is plain-convex in the ventral surface, in side-view. Following R. Buxó (1997) this type includes $T$. aestivum subsp. vulgare (Vill) Mackey, T. turgidum subsp. durum (Desf.) Mackey, and T. turgidum subsp. turgidum (L.) Mackey. On the other hand, the grains of $T$. dicoccum (Triticum turgidum L. subsp. dicoccum (Schrank) Thell.) are slender in plan view, with the upper end and sometimes the lower end pointed. Ventral surface is concave or flattish-concave in side view.

The identification of Panicum miliaceum grains followed the morphological criteria of Buxó (1997) and S. Jacomet (2006): grains are ellipsoidal to roundish in shape, with a roundish hilum. The scutellum is broad, usually oval and barely reaching half of the grains' length.

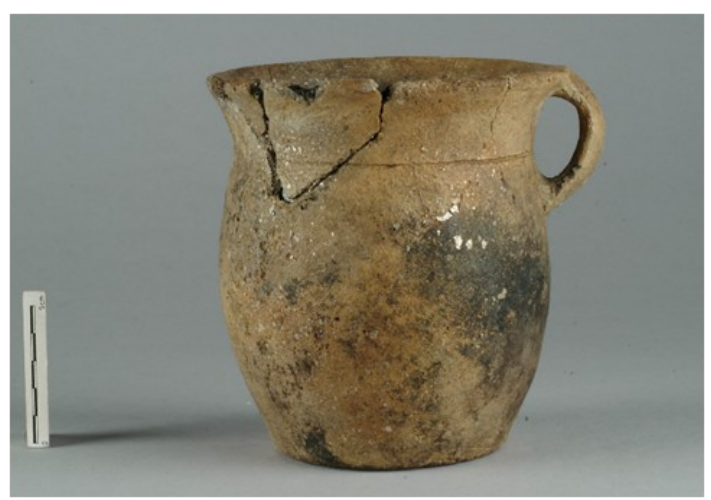

Fig. 3. Vessel (mug) from where two soil samples were collected (Photo: Manuel Santos, MDDS).

Fig. 3. Púcaro onde se recolheram duas amostras de sedimentos (Foto: Manuel Santos, MDDS). 


\section{RESULTS}

Four different taxa were identified in the samples that were studied (Table 1). Among these, there is a clear predominance of Quercus acorns with several levels of fragmentation. These are the only remains found in layer [111] being better preserved here than in layer [107], where many acorn fragments were retrieved.

Table 1. Fruits recovered in Frijão

Tabela 1. Frutos recolhidos em Frijão

\begin{tabular}{|c|c|c|c|}
\hline Layer & $107 / 402$ & 109 & 111 \\
\hline Context & $\begin{array}{c}\text { Layer in } \\
\text { the pit }\end{array}$ & $\begin{array}{c}\text { Vessel in } \\
\text { the pit }\end{array}$ & $\begin{array}{l}\text { Layer in } \\
\text { the pit }\end{array}$ \\
\hline \multicolumn{4}{|l|}{ Cereals } \\
\hline Triticum aestivum/durum - grain & 2 & & \\
\hline Triticum turgidum subsp. dicoccum - grain & & 2 & \\
\hline Triticum - grain & 1 & & \\
\hline Panicum miliaceum - grain & 1 & & \\
\hline Panicum miliaceum - aggregated grains (weight - $\mathrm{g}$ ) & c. 42 & & \\
\hline \multicolumn{4}{|l|}{ Wild-edible } \\
\hline Quercus - 2 cotyledons & 2 & & 1 \\
\hline Quercus - 1 cotyledon & 22 & 1 & 26 \\
\hline Quercus - fragment of cotyledon & 33 & 2 & 1 \\
\hline
\end{tabular}

Regarding the cereals that were recovered in layer [107], there is a predominance of broomcorn millet (Panicum miliaceum) grains. These appear mostly as small sets of aggregate grains (Fig. 4). Together with millet, we find two grains of naked wheat (Triticum aestivum/durum) (Fig. 5) and a single grain identifiable only at genus level.

The samples recovered inside the vessel provided few plant remains. The two grains of emmer (Triticum dicoccum) were found there, together with few fragments of acorns. No millet grains were recovered.

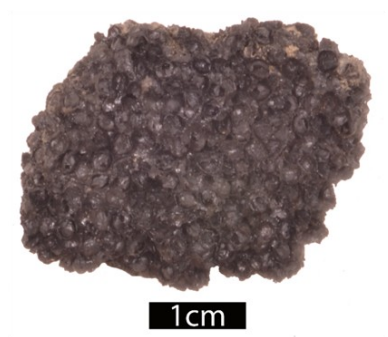

Fig. 4. Aggregated grains of Panicum miliaceum Fig. 4. Grãos agregados de Panicum miliaceum

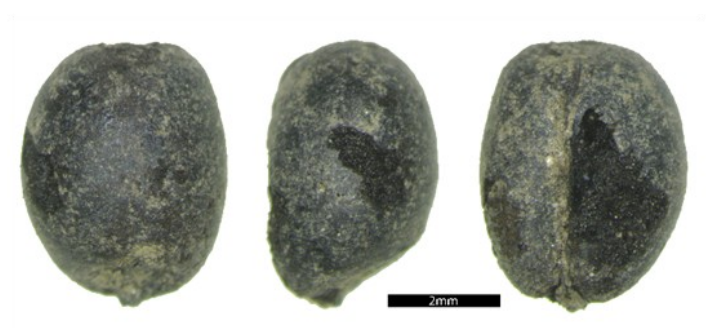

Fig. 5. Grain of Triticum aestivum/durum Fig. 5. Grão de Triticum aestivum/durum

\section{INTERPRETATION}

Unfortunately, it is impossible to know whether the plant remains retrieved in Frijão are representative of what was actually there, since there was no systematic sampling during the excavation and most remains were handpicked. This can lead to an overrepresentation of larger remains, such as Quercus acorns and the underrepresentation of smaller ones, such as millet grains. We stress that millet grains were recovered in Frijão mostly in the form of aggregate assemblages, more visible to the naked eye during the field work. It must be assumed that the lack of a proper sampling strategy probably led to a great loss of data. Such data would be of the utmost importance for the interpretation of the peculiar archaeological context registered in Frijão and for the interpretation of its carpological assemblage. This is even more striking considering that although the wild and cultivated species retrieved in Frijão are common in Iron Age contexts from NW Iberia (TERESO 2012), they are not usually found in contexts so openly related to their consumption.

The acorns and cereals of Frijão appear together with a particular set of artefacts and faunal remains in a context that has been interpreted as the result of commensality, most likely connected with any kind of ritual (SILVA 2013, 2014). Within the set of artefacts, we stress a riveted cauldron (SILVA 2013). These artefacts are usually related to intensive consumption of food and drinks, as part of highly symbolic ceremonies well beyond everyday meals (ARNOLD 1993; GONZÁlEZ RUIBAL 2006; ARMADA PITA 2005, 2008).

Thus, the fruits recovered in Frijão are likely connected with such practices, probably as part of one or more meals. The presence of cereals in such 
occasions, together with domestic animals, are well recorded in ancient Greece and they assume a determinant role in social dynamics as well as in the relation between humans and their deities (PANTEL 2008). The presence of acorns in connection with rites of commensality tallies other archaeobotanical data for the region. In fact, although the subsistence strategy of Iron Age communities in NW Iberia is based on domestic plants and animals, acorns seem to have been an important complement (TERESO 2012).

In other European areas, several Late Iron Age ritual structures related with feasting and religious purposes have been found. In some pits in France, remains of kitchen ware and other artefacts seem to be buried in some kind of communal feasting (SIMÓN 2009). In Bliesbruck (Germany), 170 big pits were found with faunal remains and drinking vessels (SIMÓN 2009), while in a pit in Lyon (France), from 120-60 BC a significant amount of Italian amphorae were deposited after the consumption of their contents during the feastings (Poux 2009).

Still, in the Portuguese territory, commensality rites are not commonly found. Such interpretation was suggested for Bronze Age funerary contexts in SW Iberia (PORFÍRIO \& SERRA 2010). It is, thus, an undervalued issue in archaeological investigation. In this way, the example of Frijão could be of great relevance if a proper field strategy would have been implemented. The study of other palaeobiological remains and artefacts from Frijão is still ongoing and they will allow a better incorporation of this site in the regional social and chronological context. It is clear, however, that sites as Frijão can open new lines of investigation regarding foodways and the social dynamics of Iron Age communities.

\section{ACKNOWLEDGMENTS}

The authors wish to thank Dr. Ana M. S. Bettencourt and Archeo'Estudos-Investigação $\mathrm{Ar}$ queológica, Lda., especially to Sandra Ralha and Paula Abrantes.

This work was carried out in the scope of a MsC thesis by Vítor Manuel Fontes Silva, with the title "A Estação Arqueológica da Idade do Ferro do Frijão (Braga, Norte de Portugal)", presented to the University of Minho in February 2014, and within the project "Espaços naturais, arquitecturas, arte rupestre e deposições na pré-história recente da fachada ocidental do centro-norte português: das acções aos significados ENARDAS" (PTDC/HIS-ARQ/112983/2009), financed by Programa Operacional Temático Factores de Competitividade (COMPETE) and with the contribute of Fundo Comunitário Europeu FEDER.

João Tereso was supported by a Post Doc grant (SFRH / BPD / 88250 / 2012) from Fundação para a Ciência e Tecnologia (national funding by MEC).

\section{REFERENCES}

ARmadA PITA, X.-L. 2005. Formas y rituales de banquete en la Hispania indoeuropea. Tese de Doutoramento, Universidade da Coruña, La Coruña.

Armada PITA, X.-L. 2008. ¿Carne, drogas o alcohol? Calde -ros y banquetes en el Bronce Final de la Península Ibérica. Cuadernos de Prehistoria y Arqueología de la Universidad de Granada, 18: 125-162.

ARNOLD, B. 1993. The material culture of social structure: rank and status in early Iron Age. Ann Arbor, Michigan.

Barbosa, R. P. \& Azevedo, M. 2004-05. A antropização da paisagem no vale do Este: dados inéditos para o seu estudo. Minia, 11-12: 113-136.

Bettencourt, A.M.S. 1999. A Paisagem e o Homem na bacia do Cávado durante o II e o I milénios $A C, 5$ vols. Tese de Doutoramento, Universidade do Minho, Braga

BetTenCOURT, A.M.S. 2005. O que aconteceu às populações do Bronze Final do Noroeste de Portugal, no segundo quartel do I milénio AC, e quando começou, afinal, a Idade do Ferro? Colóquio "Castro, um lugar para habitar". Cadernos do Museu. Museu Municipal de Penafiel: 25-40.

BuXó, R. 1997. Arqueología de las Plantas, Crítica, Barcelona.

FERREIRA, J. 2012. O povoamento no vale do rio Este do Neolítico à Idade Média: estudo preliminar. Relatório de estágio de Mestrado, Universidade do Minho, Braga.

GonzÁlez Ruibal, A. 2006. Galaicos. Poder y comunidad en el noroeste de la Península Ibérica (1200 a.C - 50 d.C.). Brigantium 18, Museo arqueolóxico e histórico castelo de San Antón, A Coruña.

Hillman, G.; Mason, S. \& Moulins, D. de; Nesbitt, M. 1996. Identification of archaeological remains of wheat: the 1992 London workshop, Circaea 12: 195 -210 .

JACOMET, J. 2006. Identification of cereal remains from archaeological sites. $2^{\mathrm{a}}$ edição, Archaeobotany Lab, IPAS, Basel University.

Martins, M. 1990. O Povoamento proto-histórico e a romanização da bacia do curso médio do Cávado. Cader nos de Arqueologia-Monografias 5. Unidade de Arqueologia da Universidade do Minho, Braga.

Medeiros, A.C. \& TeIXeIrA, C. 1969. Carta Geológica de Portugal na escala de 1/ 50 000. Notícia explicativa da folha 5-C. Serviços Geológicos de Portugal. Lisboa.

PANTEL, P. 2008. As refeições gregas, um ritual cívico. In J.L. Flandrin. e M. Montanari (Dir.), História da alimentação. 1. Dos primórdios à Idade Média. $2^{\mathrm{a}}$ edição, Terramar, Lisboa: 133-145.

Porfírio, E. \& SERRA, M. 2010. Rituais funerários e comensalidade no Bronze do Sudoeste da Península Ibérica: novos dados a partir de uma intervenção arqueológica no sítio da Torre Velha 3 (Serpa). Estudos do Quaternário 6: 49-66.

Poux, M. 2009. Banquetes y consumo del vino en la Galia a finales de la Edad del Hierro. O vinho e festa de pré -romana Europa. Universidade de Valladolid, Centro de Estudos Vacceos "Federico Wattenberg": 93103. 
RALHA, S.S. 2004. Intervenção arqueológica na escavação de empréstimo de Frijão. Zona industral da Cunha - Cunha, Braga. Relatório Final. Archeoestudos, Investigação arqueológica, Lda.

SILVA, V.M.F. 2013. Caldeiro de rebites do sítio arqueológico do Frijão (Braga, Noroeste de Portugal. Estudos do Quaternário, 9: 15-21. http://www.apeq.pt/ojs index.php/apeq.

SiLva, V.M.F. 2014. A Estação Arqueológica da Idade do Ferro do Frijão (Braga, Norte de Portugal). Dissertação de Mestrado. Universidade do Minho, Braga.

SiMÓN, F. M. 2009. Vinho, ritual e poder no mundo celta. $O$ vinho e festa de pré-romana Europa. Universidade de Valladolid, Centro de Estudos Vacceos "Federico Wattenberg": 81-92.

TERESO, J. P. 2012. Environmental change, agricultural development and social trends in NW Iberia from the Late Prehistory to the Late Antiquity. Biology Department, Faculty of Sciences, University of Porto, Porto. 